\title{
Idaho National Laboratory Ten-Year Site Plan Project / Activity Description Document
}

Descriptions of the capital projects and activities delineated in the Idaho National Laboratory 2015 - 2023 Ten-Year Site Plan as of August 2013

September 2013

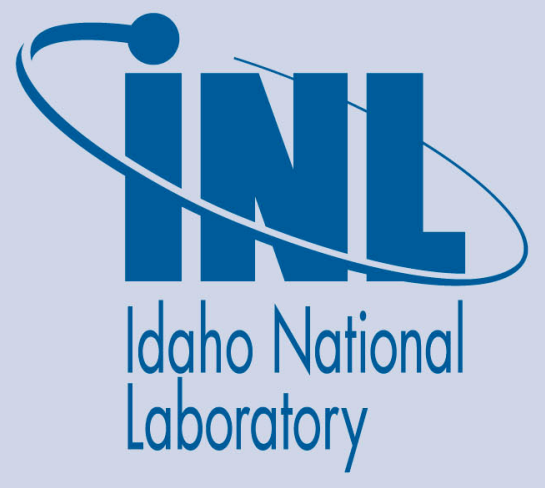

The INL is a U.S. Department of Energy National Laboratory operated by Battelle Energy Alliance 


\section{DISCLAIMER}

This information was prepared as an account of work sponsored by an agency of the U.S. Government. Neither the U.S. Government nor any agency thereof, nor any of their employees, makes any warranty, expressed or implied, or assumes any legal liability or responsibility for the accuracy, completeness, or usefulness, of any information, apparatus, product, or process disclosed, or represents that its use would not infringe privately owned rights. References herein to any specific commercial product, process, or service by trade name, trade mark, manufacturer, or otherwise, does not necessarily constitute or imply its endorsement, recommendation, or favoring by the U.S. Government or any agency thereof. The views and opinions of authors expressed herein do not necessarily state or reflect those of the U.S. Government or any agency thereof. 


\section{Idaho National Laboratory Ten-Year Site Plan Project / Activity Description Document}

Descriptions of the capital projects and activities delineated in the Idaho National Laboratory 2015 - 2023 Ten-Year Site Plan

as of August 2013

September 2013

Idaho National Laboratory

Campus Development Office

Idaho Falls, Idaho 83415

http://www.inl.gov

Prepared for the

U.S. Department of Energy

Office of Nuclear Energy

Under DOE Idaho Operations Office

Contract DE-AC07-05ID14517 



\section{Campus Development Office}

\section{Idaho National Laboratory Ten-Year Site Plan Project / Activity Description Document}

INL/EXT-13-30220

September 2013

Approved by:
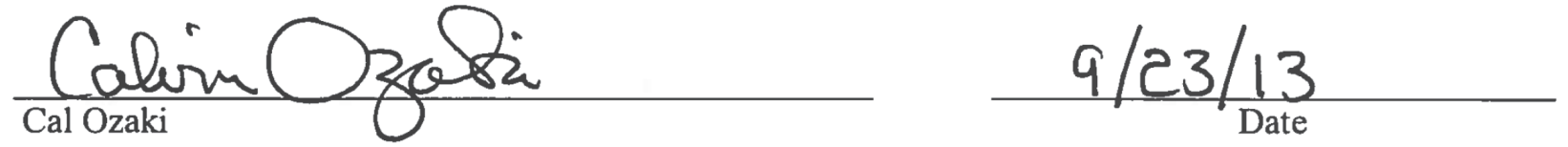

Director Campus Development Office

Facilities and Site Services

Idaho National Laboratory 



\begin{abstract}
This document describes the currently active and proposed infrastructure projects and activities listed in Appendix B of the Idaho National Laboratory 2015-2023 Ten-Year Site Plan (DOE/ID-11488) with project statuses as of August 2013. This document was produced in accordance with Contract Data Requirements List I.06.
\end{abstract}




\section{CONTENTS}

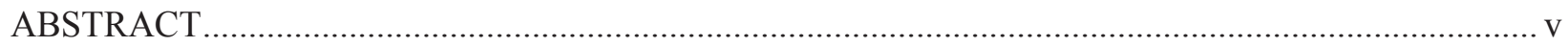

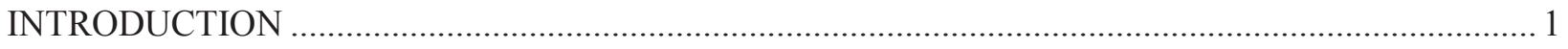

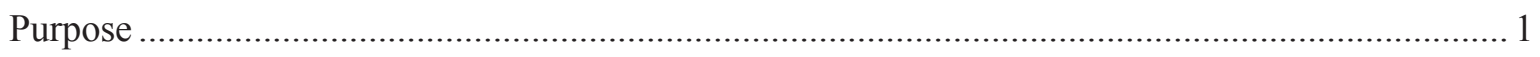

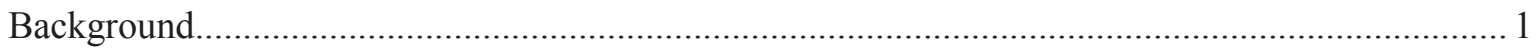

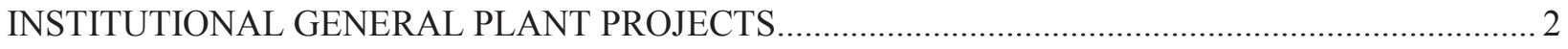

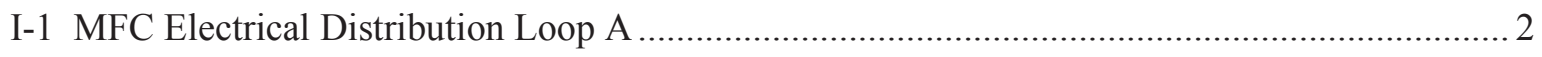

I-2 MFC Sewage Lagoon Capacity Upgrade............................................................................ 3

I-3 Obsolete IRC Fire Alarm System Replacement ............................................................... 4

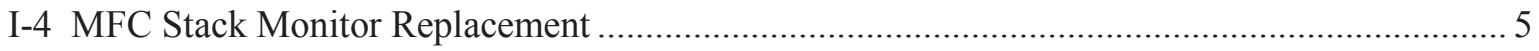

I-5 MFC Fiber Optic Backbone Capacity \& Reliability Upgrade (Manhole 50

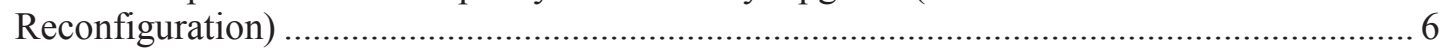

I-6 CFA-1618 Whole Body Counter/Lung Counter Annex ........................................................ 7

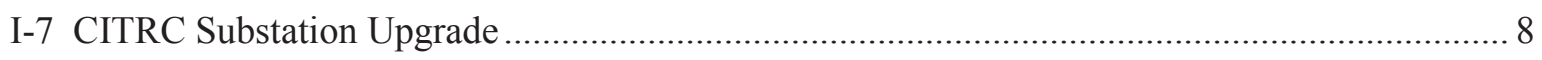

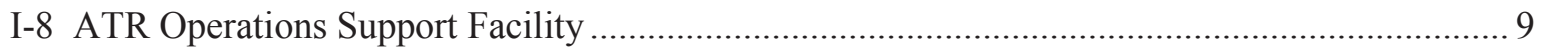

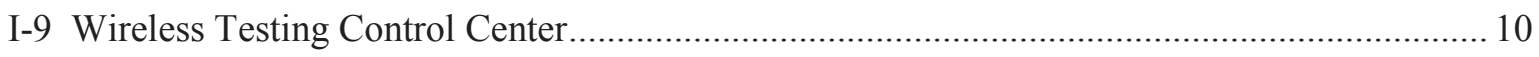

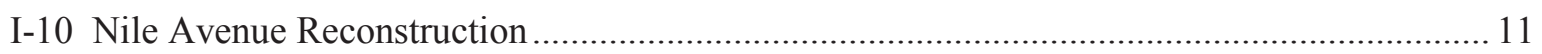

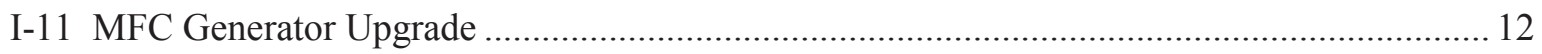

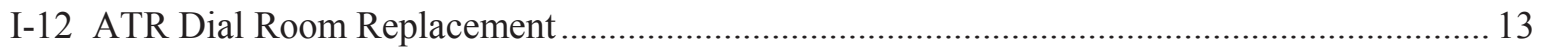

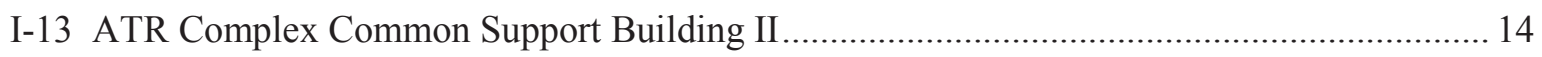

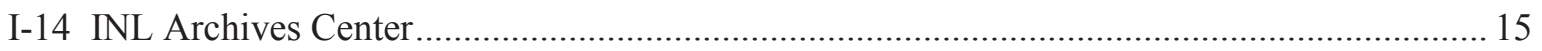

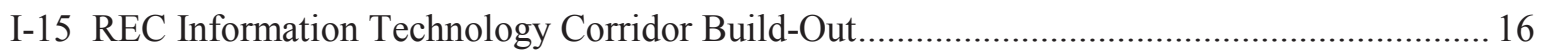

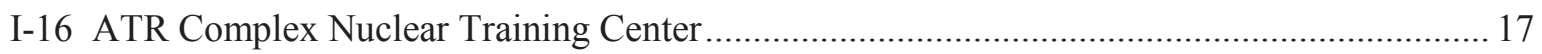

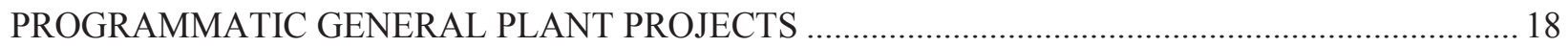

P-1 MFC-752 Analytical Laboratory Seismic Upgrade (previously MFC Analytical Lab

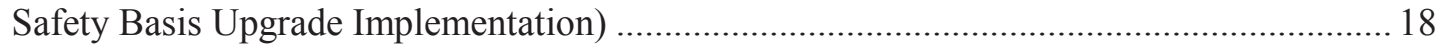

P-2 Protected Area Perimeter Equipment................................................................................ 19

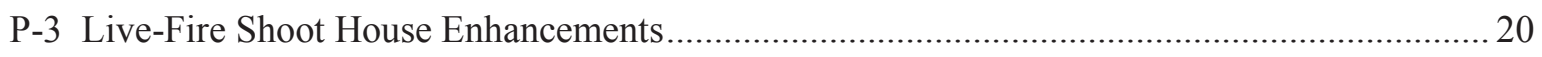

P-4 Security Technology Command and Control Space .................................................................. 21

P-5 Classified Computing Systems Infrastructure Upgrade ........................................................ 22

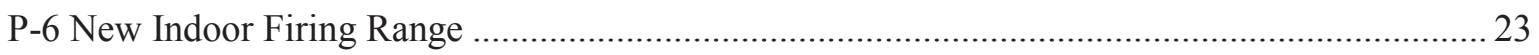

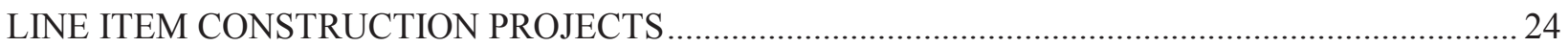

L-1 Remote-Handled Low-Level Waste Disposal Project (NE/NR) 13-D-905 (DOE-NE

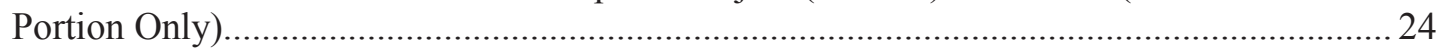

L-2 Advanced Post-Irradiation Examination Capability 13-E-200 (Project Engineering and

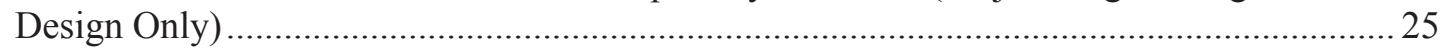

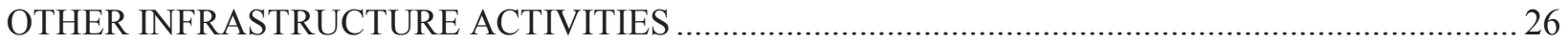

OI-1 Implement Improvements to Enable Occupancy of the Energy Systems Laboratory ........... 26 
OI-2 Implement Improvements to Enable Occupancy of the Research and Education Laboratory.....

OI-3 Expand the Space and Security Power Systems Facility to Provide Additional Radioisotope Power System Storage . 28

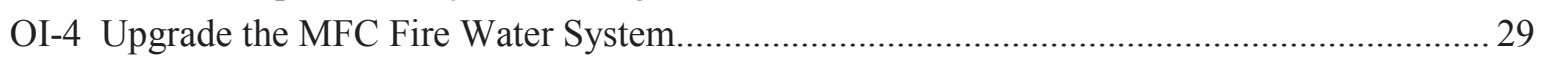

OI-5 Develop National Electric Grid Reliability Test Bed ......................................................... 30

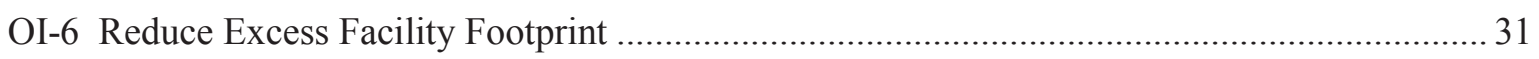

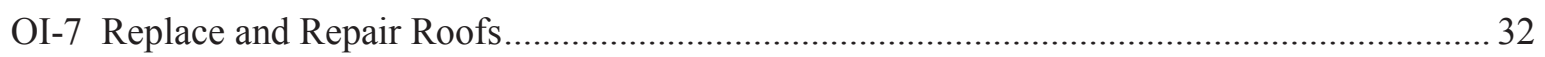

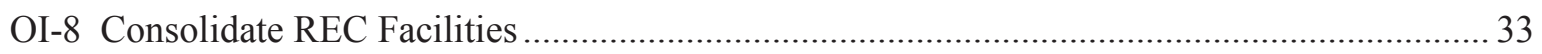

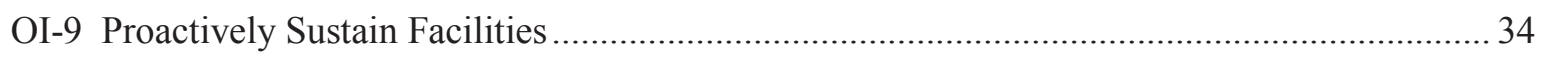

OI-10 Improve Infrastructure Sustainability Performance .......................................................... 35

OI-11 Maintain Primary Roads ............................................................................................. 36

OI-12 Replace Deteriorated Electric Power Cable to Howe Peak Transmission Facility .............. 37 


\section{Idaho National Laboratory Ten-Year Site Plan Project / Activity Description Document INTRODUCTION \\ Purpose}

This document supplements the Idaho National Laboratory (INL) 2015-2023 Ten-Year Site Plan (TYSP), DOE/ID-11488, and was produced in accordance with Contract Data Requirements List I.06. This document describes the active and proposed Institutional General Plant Projects, Programmatic General Plan Projects, Line Item Construction Projects, and Other Infrastructure Activities that are included in Appendix B of the TYSP. They are presented herein in the same order that they appear in Appendix B. The following information is provided for each project or activity:

- Problem or need addressed by the project/activity

- Project/activity description

- Mission(s) and activities supported by the project/activity

- Status of the project/activity as of August 2013.

\section{Background}

The projects and activities delineated in this document support infrastructure needs at INL's Research and Education Campus, Materials and Fuels Complex, Advanced Test Reactor Complex and the greater site-wide area. These investments will provide critical infrastructure needed to meet current and future INL operational and research needs. Execution will restore, rebuild, and revitalize INL's physical infrastructure; enhance program execution; and make a significant contribution toward reducing complexwide deferred maintenance. 


\section{INSTITUTIONAL GENERAL PLANT PROJECTS}

\section{I-1 MFC Electrical Distribution Loop A}

\section{Problem or Need}

The electrical distribution system at the Materials and Fuels Complex (MFC) suffers from aging equipment, incomplete power distribution, and improper routing of cables. Power is transmitted through old equipment from a single source, and no redundancy is provided to maintain the flow of power during either planned or unplanned outages. Communications cables are routed through the same manholes as power cables. This configuration violates the current electric code, necessitates power outages to allow work on the communications system, and potentially exposes maintenance workers to electrical hazards. In addition, security communication cables share the same duct as other communications cables. This compromises the integrity of security communications.

It is impractical to replace all of the electrical distribution system at MFC, but distributing power and communications to new locations and increasing the reliability and integrity of power and communications could be efficiently accomplished with construction of an electrical distribution loop.

\section{Project Description}

The Loop A Project will install a new electrical distribution loop starting at the MFC-711 substation and terminating at the south end of the MFC-783 Rigging Test Facility. The loop will provide permanent power to both the MFC-1729 Irradiated Materials Characterization Laboratory (IMCL) and the MFC-794 Experimental Fuels Facility (EFF). The loop will incorporate backup generator power connections and spare conduits to accommodate future needs. The project will also connect the IMCL and EFF to the state-of-the-art data communications capabilities provided by the newly completed MFC-1728 Dial Room. New fiber-optic cable will be pulled from the new dial room, through the MFC-752 Analytical Laboratory and into the entire length of the Loop A duct bank system.

\section{Asset Mission}

This project will benefit all projects performing work at MFC.

\section{Project Status}

The project is in construction. Installation of power to the IMCL and EFF was completed in September 2012. Completion of the remaining work is pending the release of the project's remaining funding. 


\section{I-2 MFC Sewage Lagoon Capacity Upgrade}

\section{Problem or Need}

The Materials and Fuels Complex (MFC) evaporative sewage lagoons are operating at full capacity and cannot support future growth or expansion. In addition, inflow/outflow data indicates that the current lagoons are leaking at an unacceptable rate.

\section{Project Description}

This project will install new evaporative sewage lagoons sized to accommodate a population of 1,150 personnel and expandable to meet the needs of 1,500 personnel, if needed. Accordingly, the project will be designed to be constructed in two stages. The design will be in accordance with Idaho Administrative Procedures Act 58.01.16-410 and will be approved by the Idaho Department of Environmental Quality. Initial lagoon installation will encompass approximately 10.5 acres. Should future needs warrant an expansion, the plans will already be in place for an additional 3.5-acre evaporative lagoon.

\section{Asset Mission}

Construction of new evaporative sewage lagoons is necessary to maintain current sewage treatment services and to accommodate MFC's projected future growth in support of the INL nuclear mission.

\section{Project Status}

The project was completed in 2012. 


\section{I-3 Obsolete IRC Fire Alarm System Replacement}

\section{Problem or Need}

The INL Research Center (IRC) fire alarm system is obsolete. Parts and technical support for most of the IRC fire alarm panels are no longer available from their manufacturers, and many replacement parts must be procured from secondary sources, such as eBay. Continued utilization of unsupported fire alarm system components increases maintenance cost and the possibility of prolonged periods of some areas not having fire event notification. Impairments also incur additional labor expense to perform fire safety inspections of unmonitored areas.

This system provides primary fire detection, alarm, and notification to staff and to the INL Fire Alarm Center (CF-1611) for IRC buildings, including four mission critical buildings.

\section{Project Description}

This project will replace the IRC fire alarm panels and communication lines with a modern and compliant "Notifier" brand system. This new, fiber-optic-based technology provides emergency responders and facility personnel with the specific types and locations of fire alarms and is being adopted as the laboratory-wide fire alarm system standard. The new system will also provide voice paging functionality that IRC currently lacks.

\section{Asset Mission}

This project will benefit all missions and programs that undertake work at IRC by improving the reliability of the fire alarm system and reducing the costs associated with alarm system impairments.

\section{Project Status}

Proposed. The Class 5 cost estimate (8B06) was completed in March 2011. 


\section{I-4 MFC Stack Monitor Replacement}

\section{Problem or Need}

INL is required to report stack emissions from the Materials and Fuels Complex (MFC) Analytical Laboratory (MFC-752) in the annual National Emission Standards for Hazardous Air Pollutants (NESHAPs) Report. The Analytical Laboratory's stack emissions are approaching a limit (0.1 millirem/year) that, if exceeded, will require the continuous monitoring of radionuclides. If the emissions were to go unmonitored, the unmitigated source term would eventually exceed the limit and INL would be out of compliance with 40 Code of Federal Regulations (CFR) 61, NESHAPs: Subpart H: Department of Energy Facilities.

The system that monitors the Sodium Wing and Non-Destructive Assay Wing emissions needs to be upgraded. The sample pump is unreliable, off-line about $25 \%$ of the time, and lacks sufficient capacity to pull appropriately sized samples. The sample transport line needs to be reconfigured and enlarged to minimize particulate deposition on interior walls prior to the point of sample collection. The system needs to be able to collect isokinetic-velocity, unbiased samples and verify the stack flow rate.

When the stack monitor system is unable to operate, all radioactive work in the Sodium Wing and the Non-Destructive Assay Wing has to be suspended, and the Analytical Laboratory's ability to perform critical work is significantly curtailed. Such curtailments impact work done in the Inductively Coupled Plasma Mass Spectrometer; the Mass Spectrometer Glovebox; three fume hoods in Room B-154; and the Non-Destructive Assay, Casting, and Mass Separator Laboratories.

\section{Project Description}

This project will upgrade the stack monitor system that tracks air emissions from the MFC-752 Analytical Laboratory Sodium and Non-Destructive Assay Wings.

\section{Asset Mission}

The project will support the multiple research and development programs and projects that conduct work in the MFC Analytical Laboratory Sodium and Non-Destructive Assay Wings.

\section{Project Status}

Proposed. 


\section{I-5 MFC Fiber Optic Backbone Capacity \& Reliability Upgrade (Manhole 50 Reconfiguration)}

\section{Problem or Need}

The Materials and Fuels Complex (MFC) fiber optic backbone is part of the optical network ring that connects each of INL's site campuses and carries all information into and out of those campuses. All internet, intranet, email, forms, and scientific and engineering data, as well as access to Battelle Energy Alliance, LLC, business applications, business data, telecommunications data, fire and security alarms, and emergency systems data sent via networked computers or systems to or from the desert campuses, pass through MFC's fiber backbone.

The MFC fiber optic backbone is currently comprised of four fibers in and out of the complex. These fibers are fully utilized, with a significant amount of information transmitted on each fiber. When a fiber connection fails, $25 \%$ of the networked communications capability to or from MFC is immediately lost and cannot be rerouted. Information processing is slowed, data is lost during transmission, and network errors are likely to occur. No spare fiber or spare capacity is available to pick up the failed fiber's information load.

Fiber failures can have a significant negative impact on MCF and INL mission performance. Furthermore, the new facilities being built at MFC will increase the amount of information flowing across each of the fibers, slow data throughput, and increase the impact of a failure.

\section{Project Description}

This project will install new inner ducts and optical fibers from the existing manhole 50, situated near the MFC-735 Guardhouse Inspection Facility, to the new MFC-1728 Dial Room. Manhole 50 will be reconfigured to allow more fibers to be added and dropped into MFC to support the research, operational, and business communications requirements at the complex.

This project will relieve the fiber optic backbone shortage and improve the distribution of information across the fibers to and from MFC and other site campuses. Additional capacity in manhole 50 will better support increased telecommunications needs imposed by new facilities and increased research work at MFC.

\section{Asset Mission}

This project will support multiple INL missions by ensuring the reliability and increasing the capacity of telecommunications services to and from MFC and other site campuses. This project supports planned MFC campus development and enables the technologies the program offices are planning to deploy.

\section{Project Status}

Proposed. The project is currently proposed for funding in FY 2015. 


\section{I-6 CFA-1618 Whole Body Counter/Lung Counter Annex}

\section{Problem or Need}

INL needs the ability to quantify low-energy radioactive material in a person's lungs, thyroid, or wound to meet the monitoring requirements specified in 10 CFR 835.402 (c) and (d) and the BEA contract with DOE. Battelle Energy Alliance, LLC (BEA) recently achieved DOE Laboratory Accreditation Program (DOELAP) accreditation for an Accuscan II system in the Central Facilities Area (CF)-1618 Health Physics Laboratory to measure high-energy radiation. However, the Accuscan II system is limited and too small to accommodate large people or those uncomfortable in small spaces.

If INL does not establish and maintain a low-energy counting capability that meets DOELAP standards, employees will need to be transported to another DOELAP accredited facility, such as Pacific Northwest National Laboratory or Los Alamos National Laboratory, for analysis when uptake of lowenergy-emitting radionuclides is suspected and rapid medical intervention (within 24-hours) may be required. Employees that cannot be counted in the Accuscan II due to physical or psychological constraints would also need to be transported to another DOELAP accredited laboratory for counting.

CH2M WG Idaho, LLC (CWI) operates a low-energy radiation counter at the Research and Education Campus in the IF-683 DOE Radiological and Environmental Science Laboratory (RESL) under a temporary Memorandum of Agreement with DOE-RESL. BEA currently buys low-energy counting services from CWI, but needs to establish its own low-energy counting capabilities before the CWI contract is completed (currently expected by October 2015) and before the old CF-690 Radiological and Environmental Sciences Laboratory is demolished.

\section{Project Description}

Prior to November 2012, CWI operated a low-energy counter in CF-690, which contains a radiation shielded vault that has 9-in. thick walls made of 7.5-in. thick pre-1945 naval steel lined with lead, cadmium, and copper. Because the vault shields the counter from background radiation, the system is optimized for low-energy radiation detection but can also measure high energy sources.

This project will construct a 900 -square foot annex to CF-1618 facility. The shielded vault currently in CF-690 will then be relocated to the CF-1618 annex to house a personnel radiation counting system. The system will be a combination of detection equipment relocated from IF-683 as well as newly acquired detection and analysis equipment. The vault will allow the counter to detect low-energy radiation. The CF-1618 annex will also include support spaces, such as office space and changing rooms.

After BEA's low-energy counting capability is established, it must accredited by DOELAP, a process that takes approximately one year to complete. Prior to applying for accreditation, the counting systems must be operable, with operating and maintenance procedures fully developed. BEA will continue to buy low-energy counting services from CWI until BEA's permanent facility at CF-1618 and associated program accreditation are complete.

\section{Asset Mission}

This project will support the entire INL, including multiple essential missions, by ensuring the continued availability of a low-energy counting capability at the Laboratory.

\section{Project Status}

Proposed. On August 3, 2011, BEA submitted a Missions Need Document (PLN-3899) to the DOE Idaho Operations Office, which outlined BEA's preferred method for maintaining the Whole Body Counting capability during the transition of dosimetry services from CWI to BEA. DOE responded to the document on March 19, 2012, indicating that they would not direct a decision concerning the transition process, but that BEA needed to continue pursuit of obtaining low-energy counting for the INL. 


\section{I-7 CITRC Substation Upgrade}

\section{Problem or Need}

The INL's existing power infrastructure has been used for conducting DOE and Work for Others projects related to power grid research since 2003. Tests have been conducted at a range of voltage levels, including the 138 kilovolt $(\mathrm{kV})$ transmission, $12.5 \mathrm{kV}$ and $13.8 \mathrm{kV}$ distribution, and 480 volt $(\mathrm{V})$ utilization levels, and have addressed operational elements that include control systems, communications, cyber security, and power quality. While most of the research and test range-related activities have been conducted within the Critical Infrastructure Test Range Complex (CITRC) infrastructure, key efforts have also been undertaken at the Idaho Nuclear Technology and Engineering Center, Materials and Fuels Complex, Central Facilities Area, and Test Area North.

Increased national interest in protecting critical power infrastructures and the resulting growth in power and control systems research at INL have significantly increased the demands on the laboratory's test capabilities. The existing test facilities on INL's transmission and distribution system have reached the limits of their ability to address key customer challenges, including limits in schedule availability, test design flexibility, and the ability to maintain minimal risk of impact to INL's operating nuclear facilities.

\section{Project Description}

This project will modify the CITRC substation to minimize the impact of test activities on the operational side of the INL's $138 \mathrm{kV}$ power distribution loop. The project will also install equipment to increase the flexibility of testing on the $13.8 \mathrm{kV}$ circuits. The project addresses issues that limit design flexibility and scheduling, and also minimizes the risk of tests impacting the laboratory's operating nuclear facilities.

The project offers a near-term, stand-alone solution to address customer requirements and demonstrate the value of INL's power grid infrastructure for research, development, demonstration, and deployment. The project will integrate seamlessly with the planned large-scale National Electric Grid Reliability Test Bed project (see Project OI-5).

\section{Asset Mission}

This project will support INL's National and Homeland Security mission to protect the nation's critical power infrastructure, and will ensure that the pursuit of that mission does not adversely impact other INL missions and operations.

\section{Project Status}

Proposed. 


\section{I-8 ATR Operations Support Facility}

\section{Problem or Need}

In about 2016, and every 8-10 years thereafter, the Advanced Test Reactor (ATR) will undergo Core Internals Changeout (CIC) to ensure its continued safe operation. CIC-associated activities will include numerous movements and lifts of large/heavy pieces of equipment and materials, requiring 40-foot below-the-hook lifts and loads greater than 20 tons. In past CICs these activities were conducted in the Engineering Test Reactor or Materials Test Reactor high bay areas. With the demolition of those facilities, no ATR Complex buildings have the necessary space, overhead clearance, and lifting capabilities. The ATR main floor and canal area cranes are essential to day to day reactor facility operations and are located in congested areas that have floor loading, lift height, and combustible material limits to ensure reactor safety. These limits make the areas under both cranes unsuitable for handling and storage of materials not directly related to the immediate operational needs of the ATR. Other INL buildings that are 5-25 miles away are capable of handling those loads, but transportation between them and the ATR Complex is impractical. Between CICs, the ATR needs high bay space to perform mockups and other on-going operations that cannot be completed in smaller spaces.

A new building sufficient in size and capability is necessary to receive, prepare, stage, assemble, and test materials and equipment in support of both the CIC and on-going operations. This facility will also be utilized to conduct mock-up training for personnel conducting the activities associated with CIC. A facility with these capabilities will eliminate the need to continue to employ less than ideal alternatives. If this building is not completed in time to support the 2016 CIC, the post CIC report will document the issues and lessons learned that result from the work-arounds required to complete CIC without high bay space at ATR.

\section{Project Description}

The ATR Operations Support Facility will include a high bay with a 30-ton crane capable of a 40-foot below-the-hook lift, and will be adequately sized and configured to accommodate both the CIC and ongoing, day-to-day operations. The building will house ATR operational support activities, including equipment mock-up and assembly, materials kitting and staging, field radiography, Industrial Health Instrument Laboratory operations, radiological controls monitoring, and quality receipt and inspection. The facility will support ATR's remaining operational lifetime through 2040.

Acquisition of this facility will reduce the transportation costs currently incurred to ship parts and materials to and from other facilities for fabrication and assembly. These savings will initially be small but will increase as the ATR National Scientific User Facility grows to include more users. Construction of this building will also eliminate the costs that would otherwise be incurred to upgrade, utilize, and maintain other buildings. The systems and structure will be new, and the facility will feature sufficient space properly configured to enable the execution of multiple projects without forcing personnel into minimally safe working conditions.

\section{Asset Mission}

The ATR Complex Operations Support Facility will provide direct support to DOE's mission to advance and develop the next generation of nuclear reactors, fuels, and materials. The facility will also support other strategic goals, such as continued irradiation of multiple fuels and materials experiments for National and Homeland Security. The building is essential to the successful completion of the CICs, mockups and other on-going operations that sustain ATR. Numerous nuclear fuels and materials will need to be tested elsewhere if ATR does not operate.

\section{Project Status}

Proposed. 


\section{I-9 Wireless Testing Control Center}

\section{Problem or Need}

National and Homeland Security (N\&HS) provides a critical National Asset Capability in protection of our nation's critical infrastructures. Wireless communications is not only one of these critical infrastructures; it is also an integral part of many of our nations control systems. To retain the highest standards in protection for this accelerating requirement, N\&HS requires a Wireless Technology Testing and Evaluation Control Center to provide simultaneous operations of multiple wireless communications tests as well as co-located office, work, and customer preparation areas. Wireless test bed Work for Others programs in critical infrastructure protection and nonproliferation are expected to continue to grow. In addition, the 2013 designation of the National Wireless User Facility at the INL will also contribute to expected growth.

Currently the wireless test bed includes three network operations centers, core system equipment, and project/customer support areas at existing facilities at the Central Facilities Area. Towers, antennas, and support equipment are located at field locations throughout the INL. The availability of additional existing facilities at the INL that would support the wireless test bed is limited. In order to support added growth, new facility space is needed.

\section{Project Description}

This project will construct a new facility to house N\&HS wireless communications control and operating systems in support of technology development, demonstration and testing. Space for equipment assembly, modification, and customer interface will be included.

The new center will have the capability to control multiple simultaneous cellular tests, enable classroom training, facilitate indoor equipment support, and coordinate reach-back conferences securely with customer home organizations away from the commotion of a network operations center. The facility will incorporate a secure, non-cellular radio equipment room for utilizing approved classified radio equipment.

\section{Asset Mission}

The Wireless Testing Control Center will directly support two INL core mission areas: Critical Infrastructure Protection and Nuclear Nonproliferation. A key focus area for both missions is ensuring that wireless communication systems used by our government are dependable, secure, and interoperable.

\section{Project Status}

A Mission Need Document has been drafted. 


\section{I-10 Nile Avenue Reconstruction}

\section{Problem or Need}

Nile Avenue is the route used by all INL buses, government and private vehicles and emergency response vehicles between Lincoln Boulevard and the Special Manufacturing Capability (SMC) main gate and is in poor condition. The road exhibits widespread degradation including cracking, rutting, raveling, and degradation of the chip seal. Immediate attention is required to maintain the safe operation of the road. The deterioration of the road is likely due to wear, poor roadbed preparation, and lack of maintenance. Nile Avenue has not received any investment in preservation or periodic maintenance in about 25 years.

Failure to take action soon could result in adverse safety conditions for those using the road. Adverse conditions could include, but are not limited to, additional potholes, standing water causing hydroplaning, and further pavement deformation that could cause drivers to lose vehicular control and/or cause damage to property and life.

In addition to employee transportation, all shipments of supplies, equipment, and products into and out of SMC utilize Nile Avenue. The Test Area North (TAN) Fire station is also located on this road. A 2010 engineering evaluation (TEV-1027) and 2011 road survey by the Idaho Transportation Department have documented the degraded condition of this road and the need to accomplish this activity.

\section{Project Description}

This project will rehabilitate and reconstruct Nile Avenue, a 1.7 mile asphalt concrete roadway connecting the SMC to Lincoln Boulevard.

This project will perform concrete recycle asphalt base stabilization to reconstruct the road bed and surface of the eastern half of Nile Avenue starting at the intersection of Nile Avenue and Lincoln Boulevard. It will also perform a fully milled and blended resurfacing of the remainder of Nile Avenue up to the SMC main gate (excluding the parking lot).

\section{Asset Mission}

This project supports all work undertaken at SMC in support of the U. S. Army, Department of Defense, and others; the TAN Fire Station, which responds to emergencies at SMC; and all facilities and activities situated in the northern portion of the INL.

\section{Project Status}

Proposed. Class 4 cost estimate (8A87-A) was completed in December 2010. 


\section{I-11 MFC Generator Upgrade}

\section{Problem or Need}

The Materials and Fuels Complex (MFC) has several small standby power generators that are loaded well below their name plate ratings. The generators are oversized, contributing to reliability and wet stacking problems, and many have few critical loads. Three generator sets failed to start during outages in 2011, and one failed twice in 16 months. Most are over 20 years old and their parts are deteriorating. Thus, starting and powering the loads is not ensured.

The INL has taken actions to mitigate the risks associated with a failure of one of these generators to start. These actions include:

- Enhanced preventive maintenance procedures to provide increased assurance of installed diesel generator readiness in order to be consistent with the National Fire Protection Association classification of each generator

- Purchased an additional portable generator.

\section{Project Description}

This project will consolidate MFC's emergency standby power generation into a reduced set of new and existing diesel generators. New generators are planned to include a $300 \mathrm{~kW}$ unit located at the MFC1729 Irradiated Materials Characterization Laboratory, another 300kW unit located at the MFC-768 Power Plant, and a 130kW unit at the MFC-720 Transient Reactor Test Facility.

The project will include the installation of new switchgear, conductors, and raceways; removal and disposal of the replaced generators; and the acquisition of the portable test load bank, cables, and facility modifications needed to facilitate routine load testing of the generators.

\section{Asset Mission}

This project will support multiple INL missions and activities by ensuring the reliability of standby power services for the benefit of all organizations that conduct work at MFC.

\section{Project Status}

Proposed. 


\section{I-12 ATR Dial Room Replacement}

\section{Problem or Need}

The Advanced Test Reactor (ATR) Complex Office Building/Bunk House (TRA-614) contains the "dial room," which houses the network communication devices and optical transport electronics that provide and support voice, video, data, fire, safety, security, and radio service for the campus. The building is 50 years old and exhibits serious deficiencies, namely, the facility floor space is exhausted; there is no room for expansion; and equipment access is limited. Additionally, the heating, ventilation, and air conditioning system is old and dysfunctional, creating undue high temperature stress on telecommunication electronics. Electrical services to the dial room are also inadequate and create a hazard to the facility, equipment, and personnel.

The ATR Complex telephone system is at very high risk (i.e., only one hardware or software breakdown away) of complete failure and loss of service for the entire campus, as illustrated by the following conditions.

- The current Private Branch Exchange (PBX) infrastructure has been in service since 1988, and the PBX switches are operating on end-of-life hardware and software

- As of October 2007, the vendor does not support or repair the hardware. After-market/secondarymarket sources have been unable to provide replacement parts, and the in-house spare hardware inventory is depleted

- Software life extension is not possible. The software was discontinued in 2007, and software patches and fixes are not available. The vendor continued to support existing installations until February 2010, but will no longer provide software patches and fixes should an issue be found within the software itself

- The ATR Complex PBXs are functioning at capacity. Telephone service for additional buildings is not available.

Because of the location and nature of deficiencies and the physical lack of floor space, repairs to the structure are unlikely and cost-prohibitive. End-of-life support issues for both hardware and software have increased the impact and risk of failure to unacceptable levels.

\section{Project Description}

This project will provide a new dial room and replace network communications equipment. A new PBX architecture will be used at ATR that requires updating some equipment at other campuses. A new master PBX switch with remote control capabilities will be installed at ATR, and two new remotely controlled replacement slave PBX switches will be installed at the Specific Manufacturing Capability (SMC) and the Idaho Nuclear Technology and Engineering Center (INTEC) campuses. The project will substantially improve the reliability of communications for ATR and PBX telephony services for all three sites.

\section{Asset Mission}

This project will support multiple INL missions by ensuring the reliability of telecommunications services for the ATR Complex and other INL operations.

\section{Project Status}

The project has completed the advanced planning/conceptual design phase (Critical Decision-1/2), but further work is on hold pending funding. Evolving laboratory priorities have resulted in rescheduling the planned project start date from FY 2013 to FY 2020. 


\section{I-13 ATR Complex Common Support Building II}

\section{Problem or Need}

The Advanced Test Reactor (ATR) Complex does not have sufficient permanent office and support space to accommodate the current staff. Over the past several years, DOE Office of Environmental Management funded footprint reduction efforts have eliminated much of the office space previously utilized to support ATR operations. The recently constructed ATR Complex Common Support Building provided 60 offices, but additional spaces are needed. ATR Complex and National Scientific User Facility (NSUF) personnel are allocated substandard space, doubled up in offices, not assigned office space, or assigned offices in Idaho Falls at the Research and Education Campus because space is not available at the ATR Complex.

The ATR Complex cafeteria is housed in an antiquated, high-maintenance structure that was designed as a warehouse and later modified for use as a cafeteria. A new office building and cafeteria are essential to continued operation of ATR. No other suitable building currently exists at the ATR Complex to provide the necessary office space.

\section{Project Description}

This project will construct the ATR Complex Common Support Building II, which will provide 40 additional offices and a cafeteria. Construction of a new office and cafeteria building will significantly improve the morale of personnel assigned to the ATR Complex. The new facility will provide sufficient office space to support multiple projects without forcing personnel into minimally safe working conditions. Operating and maintenance costs will be reduced compared to the facilities supplanted, and the new cafeteria will require less maintenance than its predecessor. The Common Support Building II will support the remaining operational lifetime of the ATR through 2040.

\section{Asset Mission}

This project will provide direct support to DOE's mission to advance and develop the next generation of nuclear reactors, fuels, and materials, as well as supporting other strategic goals, such as continued irradiation of multiple fuels and materials experiments for National and Homeland Security.

This facility will support a number of programs and activities including the NSUF, World-Leading ATR Advanced In-Reactor Experiment Instrumentation, Post-Irradiation Examination and Testing Capability, ATR Life Extension Program Activities, ATR Documented Safety Analysis and Core Safety Analysis Method Upgrades, and Core Internals Change-out.

\section{Project Status}

Proposed. 


\section{I-14 INL Archives Center}

\section{Problem or Need}

Original INL historical documents, videos, audio tapes, and other important archival media are in danger of loss from ongoing disposition activities, downsizing, outsourcing, and records management disposition schedules. INL archival data are currently housed in a facility that lacks the most basic requirements for their retention, preservation, and accessibility. As a result, inadequate identification, storage, and access for present and future INL project, program, and mission needs and preservation purposes continues to be a significant concern.

\section{Project Description}

The INL Research Center Records Storage Facility (IF-663) was constructed to provide the required environment and systems for INL's archived records, but is too small. This project will construct an addition to IF-663 to provide the additional needed on-site storage capacity for the retention, preservation, and centralized accessibility of INL archival collections.

The proposed addition is 5,500 $\mathrm{ft}^{2}$, including a $500 \mathrm{ft}^{2}$ administrative area and 5,000 $\mathrm{ft}^{2}$ storage area. Features of the addition mimic those of the existing building and include physical security, climate and lighting controls, fire suppression, and storage cabinets and shelves that are appropriate for retaining, preserving, and accessing fragile archival materials.

\section{Asset Mission}

This project will sustain the INL mission and provide research support by maintaining the historic knowledge base of mid to late $20^{\text {th }}$ century nuclear research and development, as well as land use and environmental shifts, which will be relevant to future fuel research and waste management. In addition to creating a viable and invaluable resource for the INL and providing direct and indirect support for a broad range of programs and projects at the INL, the INL Archives and Special Collections service has the potential to act as a specialized research repository for the national laboratory system and the history of nuclear research and development within the DOE.

\section{Project Status}

Proposed. 


\section{I-15 REC Information Technology Corridor Build-Out Problem or Need}

The Research and Education Campus (REC) fiber backbone carries all electronic information within, into, and out of the campus, and is part of the communication network that connects all of the INL's campuses. The fiber backbone along University Boulevard connects the research facilities (Research and Education Laboratory, Energy Systems Laboratory, Center for Advanced Energy Studies (CAES), etc.) to the laboratory's high-performance computing capabilities. All internet, intranet, email, forms, scientific and engineering data, as well as access to Battelle Energy Alliance, LLC business applications, business data, telecommunications data, safety alarms, and emergency systems data sent via networked computers or systems pass through the backbone.

The current backbone that serves all the facilities located along the University Boulevard technology corridor is subject to single point failures as a result of not being configured in a ring. Failures in cabling or communications hardware can interrupt network communications to one or more Idaho Falls facilities serviced by the network. Failures affecting multiple facilities, including extended loss of service, have already occurred. In addition, it is impossible to perform regularly required network maintenance without interrupting network availability. REC research activities have become computationally and network intensive, and even off-hour service interruptions significantly disrupt research activities and are increasingly difficult to coordinate.

Disruption of network communications severely impacts operations and limits collaborative research efforts at the INL and with partner institutions. The construction and opening of several new REC research facilities has increased the risk and impact of a backbone failure to laboratory business and a large number of science and research personnel. Reliable and secure communications are essential to the laboratory's mission success.

\section{Project Description}

This project will add to the REC backbone to achieve a ring configuration. New fiber will be run from the network terminus at CAES, south across the railroad right-of-way near the University Place campus boundary, then to the Willow Creek Building, and finally to the Engineering Research Office Building, where it will tie back into the existing network. Data will be able to flow in either direction around the ring thereby ensuring communications continuity to all University Boulevard research facilities in the event of a failure in the backbone ring.

\section{Asset Mission}

This project will benefit all INL missions and programs that undertake work at the REC by improving the reliability of network communications and eliminating the occurrence of service interruptions due to network maintenance.

\section{Project Status}

Proposed. Evolving laboratory priorities have resulted in rescheduling the planned project start date from FY 2011 to FY 2022. 


\section{I-16 ATR Complex Nuclear Training Center}

\section{Problem or Need}

The INL requires a state-of-the-art nuclear training facility that can satisfy the needs and expectations of the laboratory's nuclear industry, commercial nuclear power, and academic customers and partners. In this light, the Advanced Test Reactor (ATR) Complex ATR Simulator Training Facility (TRA-679) exhibits the following deficiencies:

- Classroom space is insufficient to meet the requirements of the training organization.

- Space for mock-ups; maintenance training; laboratory training; radiation worker training; and environmental, safety, and health training is not provided.

- The floor space is not efficiently utilized, and a clear separation between instructional space and instructor workspace is not provided.

- The facility does not provide a learning environment conducive to a systematic approach to training and the learning process.

- The building has inadequate restroom facilities and a heating and ventilation system that does not meet the requirements of a training facility.

The INL needs a Nuclear Training Center that corrects the deficiencies listed above, showcases the capabilities of the training organization, and incorporates a number of capabilities, namely:

- Dedicated space for simulators and laboratory training (e.g., Radiation Worker, Lockout/Tagout, and Maintenance)

- Sufficient classroom and classroom support space

- Environmental, safety, and health training support space

- Teleconferencing and distance learning support

- A conference room or auditorium, display space, and general purpose areas.

In addition to training activities, the facility would be used as the starting point of on-site tours and to provide briefings or overviews highlighting the organization's capabilities, resources, and the direction of future activities.

\section{Project Description}

This project will construct the necessary training, instructional, and administrative space required to support nuclear operations and the National Scientific User Facility. This could be done by building a new facility, remodeling and expanding TRA-679, or by constructing a building that connects TRA-679 and the TRA-680 Emergency Control Center.

\section{Asset Mission}

The Nuclear Training Center will interface with and support INL strategic objectives and focus areas, including: the Center for Advanced Energy Studies, the Center for Space Nuclear Research, the Center for Nuclear Fuels and Materials Research, and collaborative efforts with INL's academic partners.

\section{Project Status}

Proposed.

NOTE: Statuses are as of August 2013 for consistency with the Idaho National Laboratory 2015-2023 Ten-Year Site Plan. 


\section{PROGRAMMATIC GENERAL PLANT PROJECTS}

\section{P-1 MFC-752 Analytical Laboratory Seismic Upgrade (previously MFC Analytical Lab Safety Basis Upgrade Implementation)}

\section{Problem or Need}

The Idaho National Laboratory is currently in the process of upgrading all of its facility safety basis criteria. The Material and Fuels Complex (MFC) Analytical Laboratory (MFC-752) is one of the facilities that is currently being addressed and as a result needs major structural upgrades to meet the enhanced Document Safety Analysis (DSA) requirements. The requirements state that the building must meet performance category 2 (PC-2) seismic requirements in order to continue to operate. The facility must also meet other current natural phenomena standards, including wind and snow loading.

\section{Project Description}

The project will perform the construction activities required to bring the Analytical Laboratory into regulatory compliance. The scope of this project is broken down into 4 major portions: A, B and C wing modifications, and exterior excavation.

The new DSA requires major structural modifications to the roof and walls of the $\mathrm{A}, \mathrm{B}$, and $\mathrm{C}$ wings, as well as the basement of the facility, to achieve compliance with upgraded requirements for structural integrity. The structural inadequacies of the roof will be remedied by the construction of new roof structures over some portions of the roof and the reinforcement of other portions of the roof from inside.

The walls of the facility will also be structurally upgraded. For interior walls, the connections between the roof and the wall will be reinforced. Above-grade exterior walls will be reinforced with vertical strong backs. Some basement walls will be reinforced by installing braces on the inside to improve resistance to external soil pressure. For other basement walls, the soil load will be reduced with light-weight fill.

Other modifications will include structural reinforcement of an exhaust stack and the installation of door stoppers on the hot cell doors.

\section{Asset Mission}

Almost all work at MFC depends on the Analytical Laboratory. This project will allow that work to continue without impacts or delays. Completion of this project will bring the Analytical Laboratory into regulatory compliance.

\section{Project Status}

The project is on schedule to complete by September 20, 2013. 


\section{P-2 Protected Area Perimeter Equipment}

\section{Problem or Need}

Exterior security equipment located in the Materials and Fuels Complex (MFC) perimeter area is outdated and at end-of-life. The equipment needs to be replaced to prevent degradation leading to failure. If the equipment is not replaced, the use of additional protective forces personnel and labor will be required to compensate. The use of manual search processes as a substitute for electronic detection could result in a decreased security posture and potentially in vulnerabilities protecting special nuclear material that could be exploited by terrorists or other adversaries.

\section{Project Description}

This project will replace outdated exterior equipment in the MFC protected area including approximately 30 above ground microwave and infrared motion sensors, a buried ported coaxial cable that runs the length of the perimeter, and controlling electronics.

\section{Asset Mission}

This project will maintain appropriate perimeter security at MFC. Proper levels of security are required for the storage and use of materials at MFC and the utilization of DOE security interests at the INL. Appropriate security benefits all MFC and INL missions, programs, and employees.

\section{Project Status}

Proposed. 


\section{P-3 Live-Fire Shoot House Enhancements}

\section{Problem or Need}

The INL Shoot House (B21-626) was designed to accommodate handgun caliber ammunition. Its ballistic walls are eight feet tall and constructed with 400 Brinell hardness steel. Tactics within the DOE have evolved and require the use of rifle ammunition. Because of the current shoot house configuration, INL is required to conduct penetration testing of rifle ammunition prior to that ammunition being used in the shoot house. An upgrade to twelve foot tall 500 Brinell hardness steel walls would alleviate this testing requirement and help to mitigate additional safety concerns. In addition, the size of the current shoot house is not reflective of the environment that responders are expected to operate in at the INL, resulting in the use of different tactics in training than may be necessary in an actual security event.

\section{Project Description}

This project will remove the existing eight foot 400 Brinell steel walls, replace those with twelve foot 500 Brinell steel walls, and expand the existing footprint by adding additional rooms, wider hallways, and a stairway. The increased wall height will improve operations safety and the increase to 500 Brinell steel will improve safety and training flexibility.

\section{Asset Mission}

This project will improve physical security at the INL by improving the training of the security force. The improvements will also enhance the safety of security force training. Enhanced security benefits all INL programs and employees.

\section{Project Status}

Proposed. 


\section{P-4 Security Technology Command and Control Space}

\section{Problem or Need}

The Materials and Fuels Complex (MFC) Central Alarm Station (CAS) performs security command and control functions for MFC and the INL. The CAS is located within the MFC security perimeter, but the room is only large enough to house a single operator console. Over time, changes to the laboratory and its threat environment have significantly increased the CAS operator's work load. These changes include:

- Incorporation of MFC as part of the INL

- Addition of new intrusion detection and monitoring technology

- An increase in the threat to materials at MFC, which has resulted in the installation of additional intrusion detection and access control equipment.

These new and expanded systems are controlled by the console operator in the CAS. An attempt has been made to compensate for the increased work load by essentially installing two consoles worth of equipment and displays into one console which may prevent other important displays from being installed. A second attempt has been made to compensate by adding a second console operator during the day shift. This reduces the work overload but increases problems with overly close and cramped work space and verbal command noise levels. Also console layout optimization for two operators on the day shift is not effective for one operator on the night shift and vice versa. The work load on the CAS operator has reached the point that a second operator and console are necessary to manage daily tasks.

\section{Project Description}

This project will enlarge the CAS to provide space for one to two additional CAS operator work stations; provide work space for the monitoring and control of equipment and systems recently added by the technology deployment effort; improve heating, ventilation, and air conditioning in the area; and improve general working conditions. No new floor space will be required for the expanded CAS however it will be necessary to reassign space currently used for protective force weight training.

\section{Asset Mission}

The expanded CAS and additional console(s) will provide protective forces with the ability to efficiently monitor and control security systems at MFC. Proper levels of security are required for the storage and use of materials at MFC and the utilization of DOE security interests at the INL. Enhanced security benefits all MFC and INL programs and employees.

\section{Project Status}

Proposed. 


\section{P-5 Classified Computing Systems Infrastructure Upgrade Problem or Need}

INL's classified computing systems infrastructure is experiencing hardware and software obsolescence, leading to increased incidences of downtime and inability to accomplish classified program missions.

\section{Project Description}

This project will upgrade computing and networking hardware and software to maintain computing services to the INL classified missions. The project will provide new network transmission equipment, computing hardware and software to maintain technology currency and provide high availability to programs and operations. New network devices, servers, storage and software applications will be implemented.

As classified computing systems are consolidated and modernized, and additional capabilities are added to the Information Operations and Research Center (IORC) classified data center; higher capacity electrical distribution; uninterruptable power supplies, and heating, ventilation and air conditioning systems are required to ensure high availability to programs and operations. This upgrade supports the existing IORC classified data center and the supporting IORC dial room.

\section{Asset Mission}

This project will support all INL missions and programs that require classified computing and communications, including Department of Defense, Department of Homeland Security, and DOE classified activities.

\section{Project Status}

Proposed. 


\section{P-6 New Indoor Firing Range}

\section{Problem or Need}

The B21-608 Weapons Range House does not adequately accommodate today's security protection force training and qualification requirements that involve shooter movement and shooting while on the move. As a result, all new-hire training and firearms qualifications must be conducted on outside ranges. Weather limits outdoor range activities from October through March at the INL, but the Protective Force is required to maintain qualifications and conduct proficiency training during the winter.

\section{Project Description}

This project will construct a new indoor weapons range house adjacent to the existing Weapons Range House. The new weapons range house will have a 50-yard firing capability, 20 lane capacity, allow for shooter movement, and handle all calibers of ammunition up to and including 308 . The new range house will also include a large classroom and offices to accommodate staff and training requirements. The new indoor weapons range will include a weapons cleaning area.

\section{Asset Mission}

This project will improve physical security at the INL by improving the training of the security force. The new range house will also enhance the safety of security force training. Enhanced security benefits all INL programs and employees.

\section{Project Status}

Proposed. 


\section{LINE ITEM CONSTRUCTION PROJECTS}

\section{L-1 Remote-Handled Low-Level Waste Disposal Project (NE/NR) 13-D-905 (DOE-NE Portion Only)}

\section{Problem or Need}

Remote-handled low-level waste (LLW) is generated by INL nuclear program activities, including Naval Reactors Facility (NRF) operations and spent nuclear fuel handling and Advanced Test Reactor (ATR) Complex operations. Remote-handled LLW will also be generated by the segregation and treatment of remote-handled waste currently stored in the Radioactive Scrap and Waste Facility located at the Materials and Fuels Complex, and by future programs.

INL's current LLW disposal facility, the Radioactive Waste Management Complex Subsurface Disposal Area is planned for closure and remediation and will not be available after FY 2020.

Accordingly, INL needs to establish a new remote-handled LLW disposal capability to support ongoing and future work. Failure to replace this capability would negatively impact INL's long-term viability as the nation's lead nuclear energy laboratory.

\section{Project Description}

This project will provide on-site replacement of INL's remote-handled LLW disposal capability.

\section{Asset Mission}

This project will support DOE Office of Nuclear Energy (DOE-NE) and Office of Naval Reactors programs at INL and facilitate responsible and sound waste management. The project will:

- Provide on-going, remote-handled LLW disposal support of INL and NRF operations

- Allow continued processing of Navy fuels at NRF to support the nuclear-powered fleet while fulfilling the terms of the Idaho Settlement Agreement (State of Idaho 1995; State of Idaho 2008)

- Provide remote-handled LLW management and disposal consistent with DOE Order 435.1, "Radioactive Waste Management," which requires, "a consistent, site-wide waste management system, reducing required coordination among multiple programs to identify and implement costeffective waste management options."

- Enable continued materials testing operations at the ATR Complex once interim storage capacity is exhausted

- Facilitate future INL nuclear programs that rely on safe, compliant, remote-handled LLW disposal.

\section{Project Status}

DOE-NE approved Critical Decision (CD)-0, the Mission Need, on July 1, 2009, and CD-1, selecting a new facility for disposal of remote-handled LLW generated at the Idaho site as the preferred alternative to meet the mission need, on July 13, 2011. In accordance with the National Environmental Policy Act (42 USC $§ 4321$ et seq.), a thorough analysis of a range of reasonable alternatives was subsequently performed and, after evaluating the results of the analysis, the DOE Idaho Operations Office Manager issued a Finding of No Significant Impact on December 21, 2011. A preliminary Disposal Authorization Statement, based on the LLW Disposal Facility Federal Review Group's review of the facility's current Performance Assessment and related documentation, was received on April 2, 2012. A competitive procurement has been initiated to select a design-build contractor. CD-2/3 approval and award of the design-build contract are anticipated late in FY 2014, following authorization of a National Budget. Approval of CD-4, Start of Operations, is estimated in FY 2020.

NOTE: Statuses are as of August 2013 for consistency with the Idaho National Laboratory 2015-2023 Ten-Year Site Plan. 


\section{L-2 Advanced Post-Irradiation Examination Capability 13-E-200 (Project Engineering and Design Only)}

\section{Problem or Need}

Existing Post-Irradiation Examination (PIE) capabilities at DOE laboratories, universities, and in the private sector are widely distributed. Current PIE capabilities, such as those being established in the Irradiated Materials Characterization Laboratory, serve basic needs for fuel and material examination and handling but are limited in their capability and throughput. Collectively, the PIE capabilities within the DOE complex and at university and private sector facilities limit the ability to perform research on micro-, nano-, and atomic-scale levels, which has a significant impact on current and future nuclear fuels and materials development. A better understanding of nuclear fuels and material performance in the nuclear environment can assist in the development of innovative fuels and materials required for tomorrow's nuclear energy systems. Characterizing radioactive samples at nano-scale to micro-scale length resolutions will also support the development of modern computer codes that could enable orderof-magnitude improvements in the time and cost of developing new fuel.

\section{Project Description}

This project will complete project definition, engineering, and design for the construction of an advanced PIE capability at a location yet to be selected. The facility is anticipated to be of modular design to facilitate equipment-specific shielding solutions and to provide flexibility for future equipment deployment, configuration alteration, and replacement. The designed-in flexibility will allow the facility to remain relevant and current over a projected 40-year useful life.

The facility will feature state-of-the-art equipment and will provide a flexible footprint with a variety of laboratories in both fixed and reconfigurable space. Radiological confinement will be provided in the form of fume hoods, gloveboxes, and reconfigurable hot cells. Open laboratories will provide the space necessary to accommodate instruments with specific shielding and confinement requirements. The advanced PIE capability will serve as a national research and development center for advanced fuels and materials characterization and for development of new processes, tools, and instruments.

\section{Asset Mission}

The advanced PIE capability will support the development of accident tolerant fuels and sustainment of the existing fleet of nuclear reactors by ensuring that material degradation issues can be understood and overcome and that continued improvement in fuel reliability can be achieved. Ensuring the long-term availability of nuclear power as an energy source in the United States is the key goal of the DOE-NE Roadmap. All four Roadmap objectives will benefit from filling the current gap in advanced PIE analytical capability.

\section{Project Status}

Critical Decision-0 (Mission Need) was approved on January 31, 2011. Consistent with the FY 2012 Congressional Appropriations, approval was provided by DOE-NE on January 25, 2012, to (1) assess the benefits and options for developing a unique consolidated and comprehensive state-of-the-art facility to house advanced PIE capabilities and (2) initiate development of Critical Decision-1 (CD-1) project documents. In fulfillment of item 1, the project alternatives analysis was submitted to DOE in December 2012. To address item 2, the conceptual design report was submitted to DOE in May 2013. Other CD-1 support documents that have been submitted to DOE include the project risk management and technology maturation plans. A preliminary project safety design strategy has also been developed. Final CD-1 development is on hold pending additional funding (included in the President's FY 2014 budget) and direction from DOE. 


\section{OTHER INFRASTRUCTURE ACTIVITIES}

\section{OI-1 Implement Improvements to Enable Occupancy of the Energy Systems Laboratory}

\section{Problem or Need}

The INL Clean Energy Program, including the Bioenergy, Energy Storage, and Hybrid Energy Systems programs, continues to grow at a steady and predictable pace, but the INL facilities serving these programs are already functioning at full capacity or are inadequate to meet current or future needs. To accommodate these programs for the future, INL has leased a new 90,000 $\mathrm{ft}^{2}$ office, laboratory, and highbay facility, known as the INL Energy Systems Laboratory (ESL). However, certain program-required functionality enhancements- beyond commercial standards - that are needed to address utility; heating, ventilation and air conditioning (HVAC); information technology; security; and laboratory configuration needs are not part of the lease.

\section{Activity Description}

This activity will implement the program improvements needed to co-locate a large component of the Advanced Energy Storage, Bioenergy, and Hybrid Energy Systems programs. Specific improvements will address electrical and gas distribution, lab hood exhaust trunk installation, additional HVAC units, telecommunications, and the procurement and installation of laboratory casework and hoods. This activity will also relocate personnel and install modular office and conference room furniture. The result will be better integrated research and development of synergistic and comprehensive energy systems.

\section{Asset Mission}

Addition of the ESL to INL's current capability will accomplish an essential step towards meeting the mission needs defined for INL Energy and Environment research that addresses DOE objectives in energy supply, security, and environmental consequence. The laboratory will support field performance and live testing of advanced technology vehicles and hybrid energy systems research - an emerging area of INL research linked to renewable energy integration and alternative uses of nuclear energy.

The ESL Leasehold Improvements project directly supports the INL strategy to advance the clean energy research, development, demonstration and deployment mission. The project will configure the facility for the Feedstock Process Demonstration Unit, Hybrid Energy Systems Testing, and Battery Testing Laboratory, and will provide INL Energy and Environment Science and Technology personnel with office and laboratory space consistent with National Laboratory standards.

\section{Activity Status}

Beneficial occupancy was granted in October 2012 and personnel and equipment have been moved into the facility. Additional upgrades to the facility electrical, HVAC, and information technology systems have been completed. This project is now complete. 


\section{OI-2 Implement Improvements to Enable Occupancy of the Research and Education Laboratory}

\section{Problem or Need}

The Research and Education Campus (REC) in Idaho Falls is INL's main research campus. A primary purpose of the REC is to consolidate the laboratory's fundamental research and development activities in up-to-date, laboratory-specific, centrally located buildings adjacent to other modern facilities where complementary research is being conducted. To this end, the Laboratory has leased a new $148,000 \mathrm{ft}^{2}$ office, laboratory, and meeting center (350 person capacity) facility. However, the facility needs program-required functionality enhancements - beyond commercial standards - to address utility distribution, building systems, communications, security and occupancy needs and room configurations that were not part of the lease.

\section{Activity Description}

This activity will implement the leasehold improvements needed to accommodate Energy and Environment, National Scientific User Facility, and Nuclear Science and Technology research functions. Specific improvements will address electrical and gas distribution; heating, ventilation, and air conditioning capacity; telecommunications; laboratory casework and hoods; chemical storage; installation of a clean room; auditorium and meeting space modifications; and security upgrades. The project will also relocate personnel and equipment from other facilities (in town and at the Site) and install modular office and conference room furniture. The result will be a complete, modern, and up-to-date showcase facility that will enable leading-edge research and attract qualified researchers.

\section{Asset Mission}

The Research and Education Laboratory will support and enable world-class research and development in support of many of the laboratory's primary mission areas. These include:

- Energy and Environment Science and Technology - seventeen laboratories in chemical sciences, nanotechnology, and advanced microscopy

- Nuclear Science and Technology - seven laboratories in instrument control systems, hightemperature testing, thermal hydraulics, pyroprocessing technology, and separations technology

- National Scientific User Facility - materials characterization

\section{Activity Status}

Beneficial occupancy is scheduled for October 18, 2013. Relocating personnel and laboratory equipment is scheduled to start on October 21, 2013 and conclude by the end of July 2014. 


\section{OI-3 Expand the Space and Security Power Systems Facility to Provide Additional Radioisotope Power System Storage}

\section{Problem or Need}

Additional secure storage for fueled radioisotope power systems (RPS) and components is needed to support planned future National Aeronautics and Space Administration (NASA) and national security missions. The lack of additional storage capacity could delay completion of fueling and testing activities for NASA or other customers. In addition, mission costs will increase significantly if fueled units need to be moved to Kennedy Space Center several years ahead of launch for storage purposes.

\section{Activity Description}

This activity will construct an addition to the Materials and Fuels Complex (MFC) Space and Security Power Systems Facility (SSPSF) to provide new storage capability for fueled RPS and components. The value of fully assembled RPS units is typically $\$ 100 \mathrm{M}$ or more per item, with actual NASA mission costs roughly ten times that. The facility addition, which was envisioned when the SSPSF was originally constructed, will need to protect the integrity of the power system and be consistent with the presence of several kilograms of $\mathrm{Pu}-238$. Facility requirements include:

- Nuclear facility hazard category II facility with a performance category of 3.

- No active fire suppression system. As in the SSPSF, a fire suppression system is prohibited in the interest of assuring product quality

- Easy access from the SSPSF (MFC-792A)

- A shielded cave may also be required to enable specialized radiography.

This activity will be entirely program funded. No funding will be contributed by the laboratory.

\section{Asset Mission}

This activity will benefit all missions and activities that utilize RPS manufactured at the INL. These include NASA and various national security customers. The current projected mission planning set is large enough that the current storage capacity of SSPSF is likely to be exceeded in the next several years, and more space will be required. Existing INL facilities do not provide adequate alternatives to this expansion. Other options typically do not conform to the appropriate performance category (3) and frequently have fire suppression systems present that may affect product quality if they are activated.

\section{Activity Status}

Proposed. 


\section{Ol-4 Upgrade the MFC Fire Water System}

\section{Problem or Need}

The Materials and Fuels Complex (MFC) Water Storage Tank (MFC-754A) needs to be replaced because the tank does not meet seismic requirements and cannot be operated at full capacity. Assessments of the 200,000 gallon tank in September 2007, and again in September 2011, recommended significant repair work to ensure tank integrity. A follow-on corrective action feasibility study examined the following options: do nothing, re-coat the existing tank, or install a new tank. The feasibility study concluded that the third option, replacing the tank, is the most desirable.

Furthermore, in FY 2013 a Technical Evaluation (TEV-1827) of the Transient Reactor Test (TREAT) facility water line, the 200,000 gallon tank, and associated equipment was finalized. The evaluation determined that both the tank and the water line should be replaced. Additionally, an analysis of future needs determined that additional water storage capacity will be required to adequately support anticipated demand, including planned new construction and growth of research and development capabilities.

The TREAT area is currently supplied with potable and fire water from a combination grid and loop water distribution system at MFC. This supply consists of 4" and 6" cast iron pipes, running parallel to each other for approximately $4000 \mathrm{ft}$. This arrangement is considered unreliable and inadequate since a break in either line has a high potential to take both out and testing has demonstrated that the system cannot supply the fire protection water demands. Thus, the water supply to the TREAT area and facility requires upgrading.

\section{Activity Description}

This activity will replace the MFC-754A Water Storage Tank and install a new water line to TREAT. This effort will also bring the INL into compliance with new DOE Order 420.1 C, Facility Safety.

\section{Asset Mission}

A fully functional water storage tank and distribution system is essential to sustain on-going MFC programs.

\section{Activity Status}

The activity is currently in conceptual design and a Class 5 cost estimate is being finalized. These tasks will be complete by the end of FY 2013 and the funding determination will be finalized. This project is on hold pending availability of funding. 


\section{OI-5 Develop National Electric Grid Reliability Test Bed}

Problem or Need

An isolatable National Electric Grid Reliability Test Bed is needed to expand the laboratory's power testing capabilities and capacity and to address key national challenges that require full-scale research and testing. Additionally, modifications to the existing test bed are needed to mitigate potential impacts to INL operating facilities. Tests are currently conducted using the electrical transmission and distribution systems that supply power to INL research and development campuses. This situation places those facilities at risk of power disruptions in the event of unanticipated impacts from the tests.

\section{Activity Description}

This activity will construct a stand-alone test grid that will consist of power lines, substations, switchgear, control systems, and support facilities. It will be designed to leverage existing INL assets and unique site characteristics to meet customer needs while minimizing operational impacts to the INL. Key components include: a radial feed $138 \mathrm{kV}$ transmission line from Scoville Substation to the Critical Infrastructure Test Range Complex (CITRC), modifications to the $138 \mathrm{kV}$ switching configuration at CITRC, control room improvements at the CITRC Substation, and additional $13.8 \mathrm{kV}$ distribution lines.

\section{Asset Mission}

The power test grid will expand the laboratory's ability to investigate renewable energy and smart grid technologies, electrical distribution grid vulnerabilities and mitigation, and other critical infrastructure protection issues.

\section{Activity Status}

Proposed. The activity's mission need, technical requirements, and functional capabilities have been drafted. Funding has been requested of external customers, but no formal commitments have been established. 


\section{OI-6 Reduce Excess Facility Footprint}

\section{Problem or Need}

Fifty-seven (57) INL real property assets are currently in permanent shutdown status pending decontamination and decommissioning (D\&D). These assets include 18 buildings encompassing 141,452 gross $\mathrm{ft}^{2}$ of floor space. Additionally, INL campus planning projects an additional 253,000 gross $\mathrm{ft}^{2}$ of buildings to be declared as excess and require demolition by the end of FY 2021.

\section{Activity Description}

This activity will demolish 41 excess building assets totaling 394,694 gross $\mathrm{ft}^{2}$ by the end of 2021 . Advanced planning in the year prior to actual demolition will include processing of excess asset paperwork, performing detailed work planning for demolition, and development of the final detailed cost estimate for execution year budget planning. The principle drivers for excess asset disposition are based on the following needs:

- Reduce the cost, hazards, risk of continued asset deterioration, and visual impact associated with maintaining excess assets in the inventory for an extended period after the assets have been declared to be excess

- Improve the work environment and operational efficiency as part of campus planning activities

- Clear land area to provide for expansion or construction of new buildings

- "Bank" demolished square footage to offset expansion or construction of new square footage. Office of Management and Budget Memorandum M-12-12 directs that civilian Executive Branch departments shall not increase the total square footage of their civilian office or warehouse inventory. Acquisition of new space must be offset through consolidation, colocation, or disposal.

\section{Asset Mission}

The elimination of excess facilities benefits many INL missions and activities by reducing costs, eliminating hazards, and enhancing the work environment, as described in the preceding section.

\section{Activity Status}

Proposed. Central Facilities Area buildings totaling 47,080 $\mathrm{ft}^{2}$ have been identified for D\&D in the INL 2015-2023 Ten-Year Site Plan. 


\section{Ol-7 Replace and Repair Roofs}

\section{Problem or Need}

High-cost roof replacement activities are beyond the ability of base maintenance budgets to accomplish. This results in roof replacements being deferred until roofs have significantly degraded. This situation has contributed to increased repair cost and recurring problems with roof leaks. Roof leaks place electrical/electronic and sensitive high-cost R\&D equipment at risk and degrade employee work environment and moral. Water intrusion also soaks roof insulation and causes significant reduction in insulation and building energy efficiency.

The results of the FY 2010 roof inspection performed by the Roof Asset Management Program (updated for recent replacement activities) forecasts that one-third of the existing INL roof area should be replaced in the next three years, and about two-thirds over the next ten years. An investment of approximately $\$ 6 \mathrm{M} /$ year is projected to proactively sustain INL roofs over the next ten years.

\section{Activity Description}

This activity will accomplish higher-risk roof replacements for indirect funded DOE Office of Nuclear Energy (DOE-NE) owned buildings and mitigate the risk described in the problem/need statement above.

\section{Asset Mission}

Roofs are a key component to maintaining the enclosure integrity of INL buildings owned by DOENE. This activity will support all laboratory programs and projects that utilize indirect funded DOE-NE owned buildings at the INL.

\section{Activity Status}

Proposed. Fifteen leaking or high-risk roofs on mission critical and mission dependent facilities, as well as the roof of the EBR-I National Historic Landmark building, have been identified for replacement in the INL 2015-2023 Ten-Year Site Plan. 


\section{OI-8 Consolidate REC Facilities}

\section{Problem or Need}

Existing Research and Education Complex (REC) facilities are under-utilized. The INL is expected to efficiently utilize facilities and strategically eliminate sub-standard leased and owned facilities at the INL.

\section{Activity Description}

Evaluate existing INL facilities to develop a long term utilization strategy. Facilitate consolidation of INL facilities to ensure the most appropriate space is available to meet INL's long term mission. This will result in the early termination of sub-standard leases and the disposition (excess, demolish, etc.) of DOEowned facilities that are excess to mission needs.

Key facilities being evaluated include the IF-651 North Yellowstone Laboratory, IF-616 Willow Creek Building, IF-654 Engineering Research Office Building, IF-606 INL Administration Building, INL Research Center Complex of facilities, University Boulevard facilities, and the IF-608 Information Operations and Research Facility.

\section{Asset Mission}

This activity supports the long-term Laboratory strategic objective to improve facility utilization in order to enhance business efficiency and effectiveness through space consolidation and collocation, implementation of space standards, reduction of lease costs and reduction of the overall INL footprint.

\section{Activity Status}

The $8,000 \mathrm{ft}^{2}$ North Yellowstone Laboratory evaluation has been completed. Lease termination is planned for the second quarter of FY 2014.

The evaluation of the INL manufacturing/fabrication enterprise is underway with completion expected in September 2013. The effort will define the requirements to consolidate the entire footprint of manufacturing/fabrication capabilities with the goal of terminating the lease of the $22,030 \mathrm{ft}^{2}$ North Holmes Laboratory. Additionally, the Willow Creek Building and Engineering Research Office Building have been identified for revitalization. 


\section{Ol-9 Proactively Sustain Facilities}

\section{Problem or Need}

Funding levels have historically limited sustainment of INL real property assets to preventive, some predictive and reactive corrective maintenance. However, INL is committed to implementing deferred maintenance reduction and proactive sustainment when the risk of an unplanned failure warrants the investment necessary to "prevent" the negative impacts rather than "responding" after the failure and undesirable impact has occurred. Analysis of potential sustainment activities indicates that an investment on the order of $\$ 3 \mathrm{M}$ to $\$ 5 \mathrm{M}$ per year will be required to achieve the proactive sustainment and deferred maintenance reduction objectives.

Sustainment activities that are not accomplished when needed are reported as deferred maintenance backlog. Increases in deferred maintenance backlog result in reduction of the Asset Condition Index (ACI) for the associated asset and will eventually prevent the INL achieving DOE ACI targets.

\section{Activity Description}

Implement proactive sustainment of INL non-programmatic real property ${ }^{\mathrm{a}}$ assets except roads, roofs and electric transmission and distribution (T\&D) grid as reflected in INL integrated priority lists and multi-year maintenance and repair requirement documents. This activity does not include sustainment and revitalization of roads, repair/replacement of roofs or the electric T\&D grid which, due to their high cost, are addressed in separate activities.

\section{Asset Mission}

DOE requirements and best asset management practices drive the INL to maintain real property assets in a manner that promotes operational safety, worker health, environmental compliance, property preservation and cost-effectiveness while meeting the program mission of the Laboratory. This activity will allocate sufficient resources to accomplish proactive sustainment and deferred maintenance reduction as described above.

\section{Activity Status}

Proposed. Sustainment and deferred maintenance reduction projections are being updated annually. Specific sustainment activities addressing fire distribution; emergency electrical generation; power distribution; and laboratory heating, ventilation, and air conditioning system component replacement have been identified and prioritized for planning and execution.

a Non-programmatic real property assets are all INL real property assets except the Advanced Test Reactor, its cooling tower and the TREAT reactor.

NOTE: Statuses are as of August 2013 for consistency with the Idaho National Laboratory 2015-2023 Ten-Year Site Plan. 


\section{OI-10 Improve Infrastructure Sustainability Performance}

Problem or Need

Per federal regulations, INL is required to achieve the following sustainability-related measures as defined by the DOE Strategic Sustainability Performance Plan:

- Reduce FY 2020 Scopes 1 and 2 greenhouse gas (GHG) emissions by 28\% and Scope 3 GHG emissions by $13 \%$ from the FY 2008 baseline

- Reduce FY 2015 energy use intensity by 30\% relative to the FY 2003 baseline

- Meter individual building or processes accounting for $90 \%$ of electricity usage by FY 2015

- Install cool roofs for all roof replacements to include an insulation level of at least R-30

- By FY 2015, ensure 15\% of buildings greater than 5,000 $\mathrm{ft}^{2}$ are compliant with the Guiding Principles for High Performance Sustainable Buildings

- Ensure all new construction, major renovations, and alterations of buildings greater than 5,000 $\mathrm{ft}^{2}$ comply with the Guiding Principles

- Obtain 7.5\% of electricity from renewable sources by FY 2013

- Increase use of fleet alternative fuels by $10 \%$ annually and reduce use of fleet petroleum fuels by $2 \%$ annually, both relative to the FY 2005 baseline

- Ensure $75 \%$ of light duty vehicle purchases are of alternative fuel vehicles by FY 2020 and thereafter

- Reduce FY 2020 water use intensity by 26\% relative to the FY 2007 baseline

- Divert at least $50 \%$ of non-hazardous solid waste and as least $50 \%$ of construction and demolition materials and debris from landfill disposal by FY 2015

- Ensure procurements meet sustainability requirements and include sustainable acquisition clause (at least $95 \%$ each year)

- Meter data centers to measure a monthly Power Utilization Effectiveness and achieve a maximum annual weighted average PUE of 1.4, both by FY 2015

Progress toward meeting all 17 of these measures is required by the FY 2014 Performance Evaluation Measurement Plan, reported to the DOE Idaho Operations Office and DOE Office of Nuclear Energy annually, and results in cost savings and improved employee comfort and productivity.

\section{Activity Description}

This activity will continue to develop and install energy and water conservation activities with direct and indirect funding, promote employee participation, and modify processes and procedures to meet the goals as outlined. Energy and water cost savings will be obtained by leveraging industry and commercial level building assessments (Energy Independence and Security Act, Section 432 requirement) and through internal strategic investments.

\section{Asset Mission}

This activity will cross cut the entire INL and benefit all laboratory programs and projects.

\section{Activity Status}

This activity is meeting 10 of the 17 goals and is making progress on the remaining seven goals. The primary goals of energy and water efficiency improvements will require additional investments to accomplish assessments and upgrades. Specific metering and retro-commissioning activities are planned.

NOTE: Statuses are as of August 2013 for consistency with the Idaho National Laboratory 2015-2023 Ten-Year Site Plan. 


\section{Ol-11 Maintain Primary Roads}

\section{Problem or Need}

Base maintenance budgets are inadequate to accomplish periodic major preservation and maintenance of INL primary roads. Therefore, the road maintenance base budget should be increased, or annual strategic indirect investments allocated, on the order of $\$ 5 \mathrm{M} /$ year to properly sustain these roads.

INL primary roads require periodic maintenance investment to preserve the condition and integrity of the road surface and realize design road service life. Historically INL road maintenance budgets have only been adequate to accomplish minor maintenance (i.e., restriping, light crack sealing and pothole repair). The result is that a significant portion of these roads require preservation and maintenance (i.e., seal coating and resurfacing) to prevent further degradation and recover lost service life.

Failure to invest in periodic preservation and maintenance has resulted in loss of the road friction surface, failure of the road surface as evidenced by rutting and significant cracking, and loss of load bearing capacity of the road base due to water infiltration. These conditions ultimately result in loss of road service life, higher life cycle costs and the need for high cost total road reconstruction such as is needed to restore the condition of Nile Avenue at the Specific Manufacturing Capability.

\section{Activity Description}

Perform the periodic major preservation, maintenance and restoration activities for INL primary roads. The specific scope is outlined in the 2014 - 2016 Road Investment Proposal. Annual investment levels rage from $\$ 2 \mathrm{M}$ to $\$ 6 \mathrm{M}$ over this period.

\section{Asset Mission}

INL primary roads include the 51 miles of higher speed two-lane roads that interconnect the various mission and support complexes located across the INL desert site. They are used by INL buses, government and private light vehicles, government and private heavy haul vehicles to transport staff and materials (including properly packaged nuclear and radiological materials and waste). Mission activities for the INL, Idaho Cleanup Project and Advanced Mixed Waste Treatment Project rely on these roads to support mission activities. These roads are also used by INL emergency response vehicles.

\section{Activity Status}

Proposed. Specific primary road maintenance activities have been identified and prioritized for the period FY 2016 through FY 2023. 


\section{OI-12 Replace Deteriorated Electric Power Cable to Howe Peak Transmission Facility}

\section{Problem or Need}

The Howe Peak Transmission Facility (HPTF-604) is INL's primary transmission site for critical non-cellular wireless communications services to all INL tenants supporting the laboratory's missions. It is the only transmission site with enough altitude and line-of-site to provide radio frequency service to the laboratory and the mountainous areas INL interacts with around the site. Portions of the five mile long electric power cable to the HPTF are not buried and have been damaged and degraded by exposure to weather, physical, and wildlife hazards. This creates a significant risk of losing the HPTF commercial power supply and interrupting activities that rely on HPTF communications services.

The HPTF was designed with back-up electric power in the form of a propane fueled standby generator rated for 96 hours of operation on one propane tank. However, the Howe Peak site is very difficult to reach in the winter. In the past helicopters and snow vehicles have been used to refill the propane tank, weather permitting. Currently, INL lacks the winter vehicles with propane transporting and fueling capability that are needed to refuel the Howe Peak site.

Additionally, the HPTF is equipped with an uninterruptable power supply unit that can maintain critical systems for up to 24 hours, in the advent of a total commercial power failure and/or loss of the standby generator.

Long-duration power loss to this facility puts at risk the mission support discussed in the Asset Mission section below.

\section{Activity Description}

This activity will design and install a buried five mile long 7,200 VAC single-phase electrical power conductor to replace the damaged and degraded cable connecting the supply transformer near State Highway $20 / 33$ on the western boundary of the INL site to the transmission facility located on top of Howe Peak.

\section{Asset Mission}

This activity will benefit INL-located agencies and tenants requiring support from Howe Peak including DOE, Battelle Energy Alliance, Naval Reactors Facility, CH2M-WG Idaho, LLC, and state, and county entities. The radio frequency services provided emphasize INL Emergency Service Providers fire (both structure and wild land) and security that directly support INL operations. Additionally, the radios and pagers provided by the radio service are imbedded in nuclear operations communication processes spanning day-to-day facility operations, system anomaly notifications, daily critical data transmission, general emergency response callouts, and emergency communications at multiple complexes.

Permanent or even temporary loss of commercial electrical power at Howe Peak also impacts compliance with mandatory National Fire Protection Association regulatory requirements, DOE standards for INL's critical emergency and non-emergency communications, and critical emergency communications needs of the INL Fire and Security departments.

\section{Activity Status}

Proposed. A planning cost estimate has been requested. 